\title{
A NOTE ON EXTRADITION AND TERRORISM
}

\author{
DAVID SCHIFF*
}

The author analyzes two recent cases on the extradition of terrorists. The two cases, while procedurally and formally not inconsistent, are anomalous in substance. The author explores the political of fence exemption, the reasons for the different outcomes of the cases and makes a comparison between the treatment of anarchists and terrorists.

\section{INTRODUCTION}

Following recourse to the law in the U.S.A., Desmond Mackin, an alleged I.R.A. terrorist, was exempted from extradition to the United Kingdom;' Ziyad Abu Eain, an alleged P.L.O. terrorist, was not exempted from extradition to stand trial in Israel. ${ }^{2}$ Some aspects of the judicial proceedings in these two cases can be looked at together as an illustration of the intractability of the legal problems associated with determining the exemption status of political offenders ${ }^{3}$ from extradition. In view of attempts to achieve international cooperation to counteract terrorism, ${ }^{4}$ and particularly cooperation regarding extradition of suspected terrorists, ${ }^{5}$ the dilemmas posed by Mackin's and Eain's cases shed some light on the limitations of these international efforts.

- Visiting Professor, University of Alberta, Faculty of Law, 1982/83. Lecturer in Law, London School of Economics and Political Science.

1. U.S. v. Mackin 668 F. 2d 122 (1981).

2. Eain v. Wilkes 641 F. 2d 504 (1981).

3. Most extradition treaties and extradition statutes contain some restriction on extradition for 'political of fenders', at least since the latter half of the nineteenth century. A tyical example in the common law is the British Extradition Act 1870 section 3 which reads: "the following restrictions shall be observed with respect to the surrender of fugitive criminals: (1) A fugitive criminal shall not be surrendered if the offence in respect of which his surrender is demanded is one of a political character, or if he prove to the satisfaction of the police magistrate or the court before whom he is brought on habeas corpus, or to the Secretary of State, that the requisition for his surrender has in fact been made with a view to try or punish him for an offence of a political character." A full recent account of the political offence exemption can be found in C. Van den Wijngaert, The Political Offence Exception to Extradition: The Delicate Problem of Balancing the Rights of the Individual and the International Public Order (1980). A more dated account is B. Africa, Political Offences in Extraditon (1926). The political offence exemption has engendered a vast academic literature to which Wijngaert's selected bibliography is a reasonably good general guide.

4. For example, the Convention on the Suppression of the Unlawful Seizure of Aircraft (Hjjacking), The Hague, December 16, 1970 and The Convention on the Prevention and Punishment of Crimes against Internationally Protected Persons, Including Diplomatic Agents, December 14, 1973; see Y. Alexander, M.A. Browne, A.S. Nanes (eds.), Control of Terrorism: International Documents 1979.

5. For example, The European Convention on the Suppression of Terrorism, January 27, 1977. 


\section{THEORETICAL BACKGROUND}

System and structure theories of law ${ }^{6}$ lead inexorably to the conclusion that having formulated a legal problem in legal terms, a legal decision can inevitably be produced. The logic of these theories may lead to differing interpretations of the law and thereby differing legal decisions or outcomes, but that there always is a legal answer is uncontestable. ${ }^{7}$ How the legal decision is produced can be studied normatively, or in other ways, for example, sociologically.$^{8}$ What disturbs this packaging is the inability to generalize the means by which legal answers are achieved. Scientists always know with certainty or do not know with certainty; they deal in the production of certainties. Lawyers may like to think of themselves as dealing in legal certainties, but their efforts to attempt to do so can frequently be shown to be misplaced and misconceived. This is so because legal certainty can only reside at a formal or procedural but not at a substantive level.

This theoretical background is intended to help the reader understand the relationship between form and substance of legal discourse, which will be described in the analyses of the cases. The target of much legal theory, namely, the means of production of the legal decision, is built upon a morass of political or moral judgments often left unarticulated or undiscovered by their authors. The system and structure theories referred to tend to give a false sense of certainty to the unverifiable character of legal decision making.

\section{U.S. V. MACKIN}

What are the certainties in Mackin's case? The United Kingdom requested his extradition to stand trial for various offences including attempted murder of a British soldier. He had escaped while on bail in Northern Ireland and had entered the United States illegally. The charges against him were serious, clearly extradictable, and there was ample prima facie evidence to support them. A New York magistrate refused to extradite him on the gound that the offence charged "is regarded by the

6. H.L.A. Hart, The Concept of Law (1961), H. Kelsen, The Pure Theory of Law (translated by M. Knight, 1967); R. Dworkin, Taking Rights Seriously(1977).

7. The main thrust of Dworkin's theory is that there is a "right" legal answer. See id., especially ch. 4 "Hard Cases."

Kelsen's theory is that there is no "wrong" legal answer within a scheme of normative authorization. For example, the way that Kelsen deals with contradictory norms: "It follows that within such a normative order the same behaviour may be - in this sense commanded and forbidden at the same time, and that this situation may be described without logical contradiction." The practical way in which legal orders resolve contradictions which are logically possible (and thereby not 'wrong') is: "The two norms can be valid side by side. They can be described without logical contradiction, but they express two conflicting political tendencies, a teleological conflict. The situation is possible, but politically unsatisfactory. Therefore legal orders usually contain rules according to which one of the two norms is invalid or may be invalidated." Id. at 25-26.

8. For example, some of the sociologically produced data about the outcome of legal cases in the U.S.: E. Snyder, "The Supreme Court as a Small Group" (1958) 36 Social Forces 232; G. Schubert and D. Danielski (eds.), Comparative Judicial Behaviour (1970). 
requested Party as one of a political character ..."'The justification for such a determination was that Mackin was a member of the Provisional I.R.A. ${ }^{10}$ that the Provisional I.R.A. were involved in a political uprising in Belfast and that Mackin's alleged offences were incidental to that uprising in Belfast. Among other issues, the central grounds of appeal by the United States ${ }^{11}$ from the magistrate's decision were: that under the extradition treaty the magistrate's decision on the political offence exemption to extradition was appealable; and, that the magistrate's conclusion that Mackin's crime was of a political character was erroneous, thereby subject to the issuing of mandamus requiring the grant of extradition.

The United States Court of Appeals found against appealability. ${ }^{12}$ They cited settled case law ${ }^{13}$ and, interestingly, the clearly defined attempts by the U.S. Government to alter the law to meet this impasse. ${ }^{14}$ On the other hand, they at least admitted the possibility that they might be empowered to issue a writ of mandamus, if warranted, on the limited ground of jurisdiction. ${ }^{15}$ However, they decided that (and used Eain as relevant authority) no basis for issuing mandamus arose since the magistrate had correctly assumed the power to determine the political offence exemption. The substance of the magistrate's decision on the political exemption was thereby never questioned; nor was any attempt made to give the substance, as opposed to the power of the magistrate to make it, any legitimacy as an accurate interpretation of the law. The Court of Appeals' judgment is a restrictive one; it does not stray far from the formal issues of authorization and jurisdiction that are the content of the appeal. There is no sense, in the judgment, that the magistrate may have determined inaccurately or unwisely. A semblance of order is achieved, certainly of outcome. ${ }^{16}$

9. Extradition Treaty between the U.S. and the U.K. signed June 8, 1972, 28 U.S.T. 227, article $\mathrm{V}(1)(\mathrm{c})(\mathrm{i})$.

10. The Provisional Irish Republican Army broke with the Official Republican movement in 1969 and attempted to rekindle the rebellion against British rule in any part of Ireland. By 1971 the of fensive campaign of violence by the 'Provos' had been responded to with considerable repression by the British army. See J. Bowyer Bell, 'The Escalation of Insurgency: the Provisional Irish Republican Army's Experience, 1969-71' 35:3 (July 1973) Review of Politics 398.

11. The United States, having received a request for extradition from the United Kingdom, were acting on behalf of the U.K. in the various court proceedings.

12. The procedural devices available to alleviate the restrictions of unappealability are: that the extraditee may seek habeas corpus the denial of which is appealable; that the requesting party may shop around and refile the extradition request before another magistrate. Both of these measures of relief have limitations and problems.

13. In the Matter of Metzquer, 46 U.S. (5 How.) 176, 12 L. Ed. 104 (1847); In re Kaine, 55 U.S. (14 How.) 103, 120, 14 L. Ed. 345 (1852); and, as a comparison, the British decision Atkinson v. United States of America Government [1971] A.C. 197.

14. It was noted that since there were present attempts by the U.S. Government to reform the law on unappealability, it amounted to arguing against themselves to suggest that unappealability was not the present state of the law.

15. This is a limited ground amounting only to whether ". . . the Magistrate correctly sustained her own power to decide the political of fence question": U.S. v. Mackin, supra n. 1 at 137.

16. What is being looked at here is not criticism of the judgment as such, indeed to expect anything more from the judgment would be to expect a discussion of broad political questions beyond the competence of the judges, but how an ordered judgment is produced in the midst of substantive political issues of a difficult and disconcerting kind. 


\section{EAIN V. WILKES}

What of Eain, how certain was the outcome? Israel requested Eain's extradition to stand trial on various charges including murder and attempted murder. An Illinois magistrate determined that he should be extradited. The case arose in the Court of Appeals after Eain's attempt to have the magistrate's order overturned in a district court had failed. Eain relied on three main contentions: that the evidential requirement that he committed the crimes had not been satisfied; that the crimes were politically motivated within the political offence exemption in the extradition treaty; that Israel's request for extradition on these charges was subterfuge for their attempt to try him for the political offence of membership in the Al Fatah branch of the P.L.O.

In their judgment the Federal Court of Appeals gave a brief outline of extradition practice and law. As is common in extradition hearings, technical evidentiary problems are likely to arise. ${ }^{17}$ The main component of Eain's first contention involved evidentiary problems amounting to the questioning of the probable cause requirement for extradition. After surveying the evidence, and adjudicating on various issues of admissibility, Eain's first contention was dismissed.

In considering whether Eain's alleged offences were politically motivated the Court had to consider the government's contention that it is for the executive and not the courts to determine the political of fence exemption. They found no basis for excluding the Court's jurisdiction. In a lengthy appraisal the Court of Appeals dismissed the government's contention and stressed that not only does the Court have jurisdiction, but that that jurisdiction relates to a subject-matter about which there are standards of sufficient precision and certainty ". . . to guide the Court's discretion."18 The policy objective lying behind that determination is an attempt to ensure the protection of individual rights against possible executive expediency. ${ }^{19}$ Construction of the relevant extradition treaty seemed to the Court to be consistent with the view that a court's initial determination on the applicability of the political of fence exemption can occur prior to the executive decision on whether or not to extradite an alleged offender who is not legally entitled to the benefit of such an exemption.

In applying the law on the political of fence exemption, the Court accepted the magistrate's decision that Eain was not exempt; ". . . that the alleged bombing directed at a civilian population was not incidental to political upheaval." 20 Namely, Eain failed because he was unable to bring the circumstances of the alleged facts and his motivations within the scope of the political of fence exemption as construed by the courts. Finally, the Court determined that they had no status to consider the bona fides of Israel's request, thereby dismissing Eain's final allegation.

17. See, for example, G.V. La Forest, Extraditon to and from Canada (2nd ed. 1977) 101-107.

18. Supra $\mathbf{2} 2$ at 515.

19. Such a view would be described by Dworkin as a possible principle or right consistent with our constitutional system; see R. Dworkin, supra n. 6, especially ch. 5 .

20. Supran. 2 at 523. 
The Court's reasoning, sensitive to the difficult issues it was dealing with, shows due respect for the need to rationalize and harmonize the existing state of the law. A serious look at the details of the law had been undertaken.

\section{MACKINAND EAIN}

If these are the certainties of the two cases, what are the uncertainties? There is no obvious contradiction between the cases, indeed Eain is specifically approved of in Mackin. But despite this formal rationality, looking at the substance of the decisions, what credibility can be given to the reaching of conclusions which in effect support the distinguishing of Mackin and Eain? Mackin was exempted from extradition, Eain was subject to extradition. In effect the I.R.A. and the P.L.O. have been distinguished for the purposes of designating political objectives to those who support them. ${ }^{21}$ Surely there is a serious problem here. Where committed members of either faction allegedly commit of fences with a political motivation, it would appear to be verging on the absurd to distinguish them for the purposes of extradition law. How will one be able to predict the outcome of future similar cases involving members of other political factions? Was any substantive attempt made in either of these two cases to delineate the I.R.A. and the P.L.O.? The answer is no, and for the sound reason that to do so would involve the Courts in making a political judgment which would far outweigh their competence or jurisdiction. However, severe reservations about the state of the law arise when confronted with the apparent anomaly of distinguishing members of the I.R.A. and the P.L.O. for exemption status purposes.

\section{A. POSSIBLE DISTINCTIONS}

In the course of the decision in Eain approval is given to the magistrate's reasoning that where random bombing and murder of civilians occur, despite the political motive of the of fender, the necessary link between the aggressive act and the politically organized confrontation required for the political character designation of the of fence is not made out. Indeed Eain's alleged offences were directed at ordinary citizens of the State of Israel. Mackin's alleged of fences appeared mainly to concern a British soldier, rather than ordinary citizens. Is this good ground for the substantive distinction of the I.R.A. and the P.L.O. in these cases? It relies on a notion of proportionality ${ }^{22}$ in the political characterization of the of fences. There are some precedents for such a view particularly in Swiss authorities. In the judgment in Ktir v. Federal Public Prosecutor ${ }^{23}$ it was said that ". . . the damage had to be propor-

21. There is, of course, a vast literature on both the I.R.A. and the P.L.O. In the context of international terrorism the reader might like to look at W. Laqueur, Terrorism (1977); for references see A.R. Norton and M.H. Greenberg (eds.) International Terrorism: An Annotated Bibliography and Research Guide (1980); also, see references in this article.

22. For an account of the proportionality theory in extradition law, see Wijngaert, supran. 3 at 126-132.

23. Supreme Federal Court of Switzerland (1961) 34 Int. L. Rep. 143. 
tionate to the aim sought; in the case of murder this had to be shown to be the sole means of attaining the political aim." 24 An act of murder by an Algerian National Liberation Front member of a so-called traitor to the Front, applying these statements about proportionality, was deemed to be ". . . an act of vengeance and terror" 25 and not a political of fence for which extradition should not be granted. Such proportionality rests on the principle that not all violence can be justified as political violence, especially violence not predominantly or directly associated with the political end sought, and violence against the innocent. The Ktir case gives us a good example of non-predominance, but does it really help us with distinguishing Mackin and Eain? Being directed at ordinary, innocent citizens, Eain's alleged of fences were thought to be disproportionate to his political ends. But, who are the innocent? If Mackin's alleged offences had included the wounding of one civilian, or many civilians plus one member of the armed forces, would that have made any difference? To use the proportionality theory to distinguish these cases is unrealistic. Is there any evidence that either the I.R.A. or the P.L.O. discriminate in their campaigns so as to exclude the possibility of civilian targets? ${ }^{26}$ If they do not, then the mere coincidence that a particular I.R.A. suspect and a particular P.L.O. suspect did or did not happen to have committed offences involving ordinary citizens, is a relatively arbitrary way of distinguishing. What appears to be a rational distinction turns on an arbitrary factor of who happened to be the victim. For if we are looking at the professed aims of the organizations involved then it would be implausible to distinguish them on the grounds of their targets, since both are willing to attack citizens in order to disrupt the state.

But there still appears to be something important in the principle of proportionality which needs to be looked at further. In Eain, In re Meunier ${ }^{27}$ was used to elaborate these ideas. The relation of target or victim to offence was used to illustrate why anarchists were excluded from benefiting from the political of fence exemption. ${ }^{28}$ Perhaps:

Anarchy presents the extreme situation of violent political activity directed at civilians and serves to highlight the considerations appropriate for this country's judiciary in construing the requirements of our extradition laws and treaties.

An analogy was made from the anarchist's actions to Eain's alleged offences; namely, it was thought that both represent an unreasonable disproportion of motive for action to target of action. Hence, In re Meunier was used as justifying Eain's inability to rely on the political offence exemption. However, it needs to be pointed out that this interpretation of In re Meunier considerably extends its normal precedential value.

24. Id. at 143-144.

25. Id. at 145.

26. M. Moodie, "The Patriot Game: The Politics of Violence in Northern Ireland" and E. O'Ballance, "Terrorism in the Middle East" in M.H. Livingston (ed.) International Terrorism in the Contemporary World (1978).

27. In re Meunier [1894] 2 Q.B. 415.

28. Supran. 2 at 521. 
In re Meunier is usually cited for the denial of political offence characterization where there is a lack of political struggle between two or more parties, whereby each party is attempting to impose its form of government (as opposed to the case of anarchist motivated offences). ${ }^{29}$ The anarchist has never been the subject of the political of fence exemption, as a legal safeguard. The overall justification for such reasoning is clear: the anarchist is an enemy of all governments, not merely the particular government requesting extradition. The political of fender engaged in a particular political struggle in the requesting state would normally be thought not to be a threat to the receiving state. The conflation in Eain's case of the anarchist offender and this alleged P.L.O. offender has interesting ramifications.

In Eain, supporting the In re Meunier analogy, a general statement is made that attempts to give an overall justification for Eain's failure to gain exemption..$^{30}$

Terrorists who have committed barbarous acts elsewhere would be able to flee to the United States and live in neighborhoods and walk our streets forever free from any accountability for their acts. We do not need them in our society. We have enough of our own domestic criminal violence with which to contend without importing and harboring with open arms the worst that other countries have to export. We recognize the validity and usefulness of the political offense exemption, but is should be applied with great care lest our country become a social jungle and an encouragement to terrorists everywhere.

These words are similar to those used about anarchists at the end of the nineteenth century. What we see is the adoption of an old language to deal with new political situations. The 'terrorist' today carries the contempt of the 'anarchist' in the early part of this century. ${ }^{31}$ The terrorist puts strains on traditional legal concepts. Since no adequate legal definition of terrorism has emerged ${ }^{32}$ the implications of the use of this term tend to be neither certain nor satisfactory. The use of 'terrorist' as applied to Eain does not help us with the substantive distinction in Mackin and Eain between the I.R.A. and the P.L.O. Surely Mackin is just as much a terrorist as Eain. Use of such generic terms does not aid the judicial function, rather it involves the judiciary in political conceptualizing of a problematic kind.

29. ". . . for the party with whom the accused is identified by the evidence, and by his own voluntary statement, namely, the party of anarchy, is the enemy of all Governments. Their efforts are directed primarily against the general body of citizens" per. Cave, J., In re Meunier, supran. 27 at 419.

30. Supran. 2 at $\mathbf{5 2 0 .}$

31. Compare the Treaty for the Extradition of Criminals and for Protection Against Anarchism, Mexico City, January 28, 1902, in Y. Alexander, M.A. Browne and A.S. Nanes, supra n. 4, with the contemporary treaties on terrorism.

32. The British Prevention of Terrorism (Temporary Provisions) Act 1976, s. 14(1) defines terrorism as "the use of violence for political ends and includes any use of violence for the purpose of putting the public or any section of the public in fear." This definition seems too wide, see D. Schiff, "Law and Order - The British Response to Terrorism" 9:2 The Kingston Law Review 121. The European Convention on the Suppression of Terrorism 1977 gets away from a definition by giving a list of conduct which is meant to describe terrorist manifestations; this approach has been severely criticised, see W.H. Nagel, "A Social-Legal View on the Suppression of Terrorism" 8. International Journal of the Sociology of Law (1980) 213. 
We are left one possible further distinction. Is the I.R.A. struggle against the British State distinguishable from the P.L.O. struggle against the Israeli State? There are suggestions that the P.L.O. is a more diversified organization ${ }^{33}$ and that actions by P.L.O. members are often incidental to rather than directly part of their violent campaigns. It is clear, however, that the I.R.A. is diversified. ${ }^{34}$ Many of the actions of I.R.A. members are sectarian attacks on members of various Protestant associations and can easily be classified as incidental to their campaigns.

\section{B. WHAT CHANGE?}

What becomes clear is that the formal procedures for designating the exemption status of a political offender produce anomalous results. What needs to be asked is whether any overall change in the procedures can lessen these anomalies. The general problem is faced nearly universally. It has consistently been the case that no adequate definition of the political character of an offence has been achieved. Indeed there are good grounds why such attempted definitions should remain inadequate, or at least flexible, bearing in mind the changing nature of the political circumstances to which they may be applied. Equally, no adequate definition has met with general approval because ideological differences provide what appears to be an insurmountable hurdle to any agreed use of the term. ${ }^{35}$

The distinct legal outcomes of Mackin and Eain rest substantially on concentrating on their alleged actions and targets, rather than on themselves as actors within their organizations. With reference to the second focus, there is little or no reason to treat them differently. I.R.A. campaigns in recent times have extended outside Northern Ireland particularly onto the British mainland, but have mainly involved urban and rural guerilla tactics in Northern Ireland itself. Extensive bombing campaigns have had the political aim of forcing British withdrawal of troops from Northern Ireland. P.L.O. campaigns have consistently been directed against the Israeli population generally, Israeli interests abroad and leading Zionist sympathizers. The P.L.O. is the archetypical terrorist organization. ${ }^{36}$ It has links with other transnational terrorist organizations and acts world-wide. Because of the international ambit of its operations, it clearly contravenes the terms of the Draft Convention for the Prevention and Punishment of Certain Acts of International Terrorism. ${ }^{37}$ The 'state of war' between the P.L.O. and Israel has been a fact

33. ". . . a situation which, given the dispersed nature of the P.L.O., may be distinguished." Supran. 2 at 519.

34. Among those republican organisations which are illegal under the Northern Ireland (Emergency Provisions) Act, 1978 s. 21 are the Official I.R.A., the Provisional I.R.A., the Irish National Liberation Army (I.N.L.A.), Cumann nam Bah, Fianna na h Eire ann, Soar Eire.

35. See W.H. Nagel, supra n. 32; N.N. Kittrie 'A New Look at Political Offences and Terrorism' in M.H. Livingston (ed.) supra n. 26 at 354.

36. Particularly with respect to its international character and the international terrorist network which it has engendered. See E.S. Ellenberg 'The PLO and its Place in Violence and Terror' in M.H. Livingston, supra n. 26 at 165; J. Bowyer Bell, Transnational Terror (1975) 56-68.

37. Submitted by the United States to the U.N. General Assembly, September 26, 1972. 
of Middle Eastern politics since Al Fatah came into existence. Such a fact is denied by none of the relevant parties. The I.R.A. is less international and less likely to act beyond traditional targets. ${ }^{38}$ The position of the activist wing of the I.R.A. is less clear cut. There have been times since the partitioning of Ireland when the I.R.A. as an active political force has been very weak, and the arbitrary acts of some of its members would not have satisfied the basic tests of political offences in the standard common law authorities, especially In $R e$ Castioni. ${ }^{39}$ Also, of course, the British government denies the status of political of fenders to I.R.A. members. ${ }^{40}$

Surely there is a good argument that both Mackin and Eain should be exempted from extradition, or neither should be. In the light of the 'terroristic' character of the organizations involved, and in view of recent developments in extradition law in relation to terrorism, it can be suggested that the political offence loophole would become increasingly more difficult to slip through. In Europe, following the European Convention on the Suppression of Terrorism, 1977, as between member states who have incorporated the Convention into their law, extradition of 'terrorists' has become more likely by limiting the political offence exemption. ${ }^{41}$ For the Convention excludes the possibility of arguing the political of fence exemption where the offence contravenes various civil aviation conventions, is directed against internationally protected persons including diplomats, involves hostage taking or "the use of a bomb, grenade, rocket, automatic firearm or letter or parcel bomb if this use endangers persons." 42 Also, the revulsion of many states at the 'haven' given to terrorists by some countries ${ }^{43}$ poses great strains on the good faith of the courts not to be politically influenced against the political offender. ${ }^{44}$ Since international agreement beyond what we have seen ${ }^{45}$ is unlikely, judicial contraction of the political offence exemption is probable with regard to what is loosely termed as terrorism.

38. Which, of course, does not mean that it has not so acted, or might not change its course. See, A. O'Day "Northern Ireland, Terrorism, and the British State" in Y. Alexander, D. Carlton and P. Wilkinson (eds.) Terrorism: Theory and Practice(1979) 121.

39. [1891] 1 Q.B. 149.

40. As example the hunger strike campaign by Bobby Sands and others to achieve among other things political status in prison.

41. The Convention has been ratified in Britain and brought into domestic enactment by the Suppression of Terrorism Act 1978. At the same time other changes in existing extradition practice are restricting the scope of individual protection, see D. Schiff "Astrid Proll's case" Public law (1979) 360-365.

42. Article 1(e.).

43. Especially Libya.

44. See the passage quoted earlier in this article from Eain v. Wilkes, supra n. 2 at 52 for a clear example of this strain.

45. On hijacking and other transportation of fences, internationally protected persons and extradition. Draft treaties beyond these areas have not been accepted; see Y. Alexander, M.A. Browne and A.S. Nanes, supra n. 4 at 113-131. Also, more generally, see N.C. Livingstone, the War against Terrorism (1982). 


\section{ANARCHISM AND TERRORISM}

It is in the conflation of the anarchist and the terrorist that the further interpretation of the political of fence exemption is likely to occur in the U.S.A. and other common law jurisdictions. Such a conflation would show the decision in Mackin to be seriously out of line. ${ }^{46}$ We can anticipate that by extending the principles of proportionality and predominance of political aims to action taken, ${ }^{47}$ and by focusing more on the relationship of the offenders to the organizations they are associated with, some principle about the non-applicability of the political offence exemption to terrorists is likely to emerge, as an equivalent of its non-applicability to anarchists. The vocabulary of this change is likely to involve the sort of generalized statements about the threat of terrorists that was earlier quoted from Eain. Those who are willing to resort to extreme forms of violence, like the anarchist, will be classified as too dangerous to receive the humanitarian protection of the political offence exemption. The transnational character of terrorism gives the link for this reasoning. Not only are terrorists likely to attack beyond the bounds of the state against which their actual conflict lies, but some terrorists have been willing to act in the cause of others. ${ }^{48}$ Under these conditions, in the ambit of the political of fence characterization, the language used about the anarchist is likely to be transposed to deal with the terrorist, without, however, the possibility of an adequate definition of terrorist arising.

\section{REAL CHANGE?}

To meet some of the problems addressed in this article, as well as other related problems, proposals for change have emerged through the course of international dialogue. ${ }^{49}$ The most characteristic of these proposals are: to reduce the ambit of the political of fence exemption, ${ }^{50}$ to extend jurisdiction over terrorist crimes by imposing an obligation on states either to extradite or to try alleged offenders (for example, by creating extra-territorial criminal offences), ${ }^{51}$ to encourage states to cooperate over the 'informal' removal (eg. deportation) of alleged of fenders to avoid the protections of extradition. ${ }^{52}$ The direction of change is clear-a

46. Of course there will be those who will argue that the real reasons for Mackin's exemption and Eain's non-exemption were the I.R.A., Irish and Jewish lobbies in the United States, and their subliminal influences.

47. As was done in Eain v. Wilkes, supra n. 2.

48. See C. Dobson, The Carlos Complex: a pattern of violence (1977).

49. See J.F. Murphy, Legal Aspects of International Terrorism: Summary Report of an International Conference (1978); Council of Europe, Conference on the Defence of Democracy against Terrorism in Europe: Tasks and Problems (1980).

50. There clearly has been a judicial narrowing in a number of jurisdictions: Cheng v. Governor of Pentonville Prison [1973] A.C. 931 in the U.K.; Piperno, Court of Appeal of Paris, October 17, 1979, see Le Monde October 19, 1979 p. 14, in France; Germany v. Pohle, Federal Constitutional Court of Germany 1977 in L.C. Green, International Law Through the Cases (4th ed. 1978) 383.

51. E.g. European Convention on the Suppression of Terrorism 1977 Articles 6 and 7.

52. See P. O'Higgins, “Disguised Extradition: The Soblen Case" (1964) 27 The Modern Law Review (1964) 521; T. E. Carbonneau, "Extradition and Transnational Terrorism: A Comment on the Recent Extradition of Klaus Croissant from France to West Germany"' (1978) 12 Int. Lawyer 813. 
many-sided attempt to reduce the protections previously given to the political offender. The consequences for the traditional common law protection of individual liberty through habeas corpus applications is to limit the scope of that remedy. ${ }^{53}$ But can we draw any more general conclusions about the reality of these changes?

Shouldn't we be asking the question whether the political offence exemption to extradition fits the conditions of modern political conflict? The genesis of the idea of the political offence exemption was something to do with distrust of the objectivity or fairness of the legal systems of other countries, and, in many situations which still exist today, an unwillingness to send a 'friend' back to suffer at the hands of an enemy ${ }^{54}$ Are these protections, the procedures devised to operate them or the reasons for employing them, still appropriate in the contemporary world? Interdependence in the world today has brought new problems, not least of which is the development of international terrorism and the broadening of the local political conflict to the international arena. The protection given to Mackin to avoid having to stand trial in Britain for his alleged offences, based as it is on traditional legal principles which are necessary to protect the individual from political persecution, nevertheless amounted to a serious interference in internal political conflicts within the United Kingdom. Such interference appears to be out of line with the changes that are occurring. The direction of change (which Mackin seems to contradict), in fact, amounts to this: as a necessary part of the cooperative effort to reduce terrorism, it has become essential to avoid interference in the internal politics of other states, even though this is achieved at the expense of a traditional protection of individual freedom. The cooperative effort to reduce terrorism, which tends to wither away the rights of political activists, is accompanied by the assertion that such effort is necessary to protect democracy and human rights. Such an assertion highlights the paradox that often more freedom for some goes hand in hand with less freedom for others.

53. For a full account of the remedy of habeas corpus see R.J. sharpe, The Law of Habeas Corpus (1976).

54. Isn't this, perhaps, the best rationale of the decision in Ex p. Kolczynski [1955] 2 W.L.R. 116 ? See case note by W.E. Denny (1955) 18 The Modern Law Review 380. 